\title{
TINJAUAN PROSES PELAPORAN EKSTERNAL DI BAGIAN PELAPORAN RUMAH SAKIT UMUM DAERAH PANDAN ARANG BOYOLALI
}

\author{
Ngatmi Setyo Rini ${ }^{1}$, Antik Pujihastuti ${ }^{2}$ \\ ${ }^{1,2}$ STIKes Mitra Husada Karanganyar \\ rinisetia100@yahoo.co.id, att2a2000@yahoo.com
}

\begin{abstract}
Pandan Arang Local General Hospital of Boyolali had made SIR VI transfer in 2013. The delayed delivery of external reporting when submitting the external report data still becomes the obstruction due to the billing system not supporting the necessary data in the report, to the management of hospital's less readiness in the transformation of Standard Operating Procedure about reporting. The objective of research was to find out the external reporting process in reporting division of Pandan Arang Local General Hospital of Boyolali. This study was a descriptive research with cross-sectional approach. The subject of research was the analyzing reporting personnel in Pandan Arang Local General Hospital of Boyolali, while the object of research was external reporting process. The research instrument employed was observation. The methods of collecting data used were observation and unstructured interview. Technique of processing data included data collection, editing and display. The data analysis was conducted using descriptive analysis. The result of research showed that data source and reporting type had been consistent with the data the hospital required. The External reporting process was conducted manually and in computerized manner. In manual method, the analyzing reporting personnel submitted data by visiting each unit once a month and the officer recapitulated the data into Microsoft Excel and data was linked to SIMRS, it led the officers to work twice. The conclusion of research was that the external reporting process in Pandan Arang Local General Hospital of Boyolali was conducted manually and in computerized manner, for that reason, the billing system should be maximized in each unit for the analyzing reporting officer not to take longer time to retrieve the necessary data for reporting.
\end{abstract}

Keywords: External reporting SIRS VI

\begin{abstract}
Abstrak
RSUD Pandan Arang Boyolali telah melaksanakan perpindahan SIRS VI pada tahun 2013. Kejadian terlambatnya pengiriman pelaporan eksternal saat pengumpulan data pelaporan eksternal masih terdapat kendala disebabkan karena sistem billing yang tidak dapat menunjang data-data yang dibutuhkan dalam pelaporan, Kurang siapnya manajemen rumah sakit dalam perubahan Standar Operasional Prosedur tentang pembuatan laporan. Tujuan penelitian mengetahui proses pelaporan eksternal dibagian pelaporan Rumah Sakit Umum Daerah Pandan Arang Boyolali. Jenis penelitian ini deskriptif dengan pendekatan cross sectional. Subyek dalam penelitian ini adalah petugas analising reporting di RSUD Pandan Arang Boyolali, sedangkan obyek yang digunakan adalah proses pelaporan eksternal. Instrumen penelitian menggunakan observasi. Cara pengumpulan data menggunakan observasi dan wawancara tidak terstruktur. Teknik pengolahan ini menggunakan collecting, editing, penyajian data. Analisis data menggunakan analisis deskriptif. Hasil penelitian menunjukkan bahwa sumber data dan jenis pelaporan sudah sesuai dengan data yang dibutuhkan rumah sakit. Proses Pelaporan Eksternal dilakukan secara manual dan komputerisasi. Dari cara manual petugas analising reporting mengumpulkan data dengan datang ke setiap unit dan dilakukan sebulan sekali dan petugas merekapitulasi data ke Microsoft excel dan data di link kan ke SIMRS, hal ini mengakibatkan petugas harus bekerja dua kali. Simpulan hasil penelitian bahwa proses pelaporan eksternal di RSUD Pandan Arang Boyolali yaitu proses pelaporan dilakukan manual dan komputerisasi oleh karena itu perlunya memaksimalkan sistem biling disetiap unit agar petugas analising reporting tidak mebutuhkan waktu lama untuk mencari data yang dibutuhkan untuk pelaporan.
\end{abstract}

Kata Kunci: Pelaporan Eksternal SIRS VI 


\section{PENDAHULUAN}

Rekam medis merupakan salah satu sumber data dalam pembuatan pelaporan di rumah sakit. Pelaporan rumah sakit merupakan suatu alat organisasi yang bertujuan untuk dapat menghasilkan laporan secara cepat, tepat dan akurat. Statistik kesehatan merupakan bagian dari kegiatan di bidang rekam medis, yang dikerjakan di bagian pelaporan. Kegiatan pelaporan terdiri dari pengumpulan data statistik rumah sakit untuk pemenuhan pembuatan pelaporan bersumber dari register, sensus harian dan indeks. Pengumpulan data dalam pembuatan pelaporan memerlukan suatu kerjasama yang baik, maka data yang diperlukan akan lebih mudah terkumpul dan pengolahan data dapat segera dilakukan.

Berdasarkan survey pendahuluan di Rumah Sakit Umum Daerah Pandan Arang Boyolali pelaporan eksternal telah beralih ke SIRS revisi VI mulai tahun 2013. Tetapi pada saat pengumpulan data pelaporan eksternal masih terdapat kendala yang disebabkan karena sistem billing yang tidak dapat menunjang data-data yang dibutuhkan dalam pembuatan pelaporan eksternal, hal ini mengakibatkan petugas analising reporting tidak dapat menyelesaikan tugasnya dengan baik, dilihat dari pembuatan pelaporan eksternal yang sering terlambat. Kurang siapnya manajemen rumah sakit dalam perubahan Standar Operasional Prosedur tentang pembuatan laporan, dengan hal tersebut petugas analising reporting akan kebingungan dalam melaksanakan tugasnya.

Oleh karena itu peneliti tertarik untuk mengambil judul "Tinjauan proses pelaporan eksternal di bagian pelaporan Rumah Sakit Umum Daerah Pandan Arang Boyolali”.

\section{METODE PENELITIAN}

Jenis penelitian yang digunakan adalah penelitian deskriptif. Penelitian deskriptif digunakan untuk menganalisis data dengan cara mendeskripsikan atau menggambarkan data yang telah terkumpul sebagaimana adanya tanpa bermaksud membuat kesimpulan yang berlaku untuk umum atau generalisasi. Dalam penelitian ini terkait dengan proses pelaporan eksternal di bagian pelaporan rumah sakit. Rancangan penelitian yang digunakan adalah pendekatan cross sectional yaitu pengambilan data yang dilakukan dalam satu waktu atau dalam suatu periode tertentu. Obyek penelitian ini adalah proses pelaporan eksternal SIRS VI di Rumah Sakit Umum Daerah Pandan Arang Boyolali. Subyek penelitian ini adalah petugas bagian analising reporting di Rumah Sakit Umum Daerah Pandan Arang Boyolali.

Instrumen Penelitian data ini adalah pedoman observasi dalam bentuk checklist yang digunakan untuk alat observasi dalam proses pelaporan eksternal SIRS VI. Cara Pengumpulan Data dengan observasi yaitu suatu proses pengamatan terhadap data yang akan diteliti berupa proses pelaporan eksternal berdasarkan SIRS VI dan wawancara tidak terstruktur yaitu wawancara bebas tidak menggunakan pedoman wawancara yang telah tersusun secara sistematis untuk pengumpulan datanya.

Tahapan Pengolahan data yaitu dengan pengumpulan (collecting), edit (editing), penyajian data . Analisis data yang digunakan adalah deskriptif dengan cara menguraikan keadaan yang diperoleh, yang dapat digunakan untuk pengambilan kesimpulan berdasarkan hasil dari pengamatan di lapangan dan teori yang terkait dalam tinjauan pustaka.

\section{HASIL}

1. Sumber Data dan Jenis pelaporan yang digunakan pada pelaporan eksternal di Rumah Sakit Umum Daerah Pandan Arang Boyolali

a. Sumber Data yang digunakan pada pelaporan eksternal di Rumah Sakit Umum Daerah Pandan Arang Boyolali :

1) RL 1 data dasar rumah sakit bersumber dari indicator pelayanan rumah sakit dan fasilitas tempat tidur.

2) RL 2 yang bersumber dari buku register ketenagaan yang terdiri dari item keadaan, kebutuhan yang mengisi data ketenagaan adalah bagian ketenagaan.

3) RL 3 yang bersumber dari buku register di setiap unit rawat inap, kesehatan gigi dan mulut, radiologi, laboratorium, fisiologi, rehabilitasi medik, psikologi, semua buku register tersebut terdiri dari item nomor rekam medis, nama, umur, jenis kelamin, alamat, diagnosis, jenis pelayanan.

4) RL 4 data morbiditas dan mortalitas yang bersumber dari indeks penyakit 
yang terdiri dari item nomor rekam medis pasien, jenis kelamin, umur, diagnosa lain, dokter lain, hari perawatan, meninggal atau keluar (sembuh atau cacat) dan indeks kematian yang terdiri dari item nomor, nomor rekam medik, nama, tanggal masuk dan keluar, hari perawatan, umur, jenis kelamin, ruang, alamat, pekerjaan, pendidikan, komplikasi, operasi. Dari kedua indeks tersebut digunakan untuk entri data pelaporan eksternal oleh petugas indeksing berjumlah satu orang yang dientri pada komputer

5) RL 5 data bulanan yang bersumber dari data pengunjung rumah sakit, laporan kunjungan rawat jalan diperoleh dari bagian petugas rawat jalan yang terdiri dari item nomor KIUP, nama pasien, umur, alamat, tempat pelayanan, karcis, karcis penjamin, penjamin. Data 10 besar penyakit rawt inap, data 10 besar penyakit rawat jalan.

6) Formulir Sensus Harian Rawat Inap diperoleh dari masing-masing perawat bangsal yang terdiri dari item nama, tanggal masuk, tanggal keluar, nomor rekam medis, ruang rawat inap, kelas perawatan, TT tersedia, keluar rumah sakit.

2. Jenis Pelaporan yang digunakan untuk pelaporan eksternal di Rumah Sakit Umum Daerah Pandan Arang Boyolali

a. RL 1 berisikan Data Dasar Rumah Sakit yang dilaporkan setiap waktu apabila terdapat perubahan data dasar dari rumah sakit sehingga data ini dapat dikatakan data yang yang bersifat terbarukan setiap saat (up to date).

b. RL 2 berisikan Data Ketenagaan yang dilaporkan periodik setiap tahun

c. RL 3 berisikan Data Kegiatan Pelayanan Rumah Sakit yang dilaporkan periodik setiap tahun.

d. RL 4 berisikan Data Morbiditas atau Mortalitas Pasien yang dilaporkan periodik setiap tahun.

e. RL 5 yang merupakan Data Bulanan yang dilaporkan secara periodik setiap bulan, berisikan data kunjungan dan data 10 (sepuluh) besar penyakit.
3. Proses Pelaporan Eksternal di Rumah Sakit Umum Daerah Pandan Arang Boyolali

Proses pelaporan eksternal di Rumah Sakit Umum Daerah Pandan Arang Boyolali mulai menggunakan SIRS VI pada tahun 2013, yang dilakukan oleh petugas analising reporting yang berjumlah satu orang. Proses pelaporan eksternal SIRS VI dilakukan dengan menggunakan dua komputer yaitu satu komputer untuk SIMRS dan satu komputer untuk merekapitulasi data. Proses pelaporan eksternal SIRS VI dilakukan dengan dua cara yaitu secara manual dan komputerisasi. Proses pelaporan secara manual petugas analising reporting mengumpulkan data dengan datang ke setiap unit dan dilakukan sebulan sekali, setelah data terkumpul petugas merekapitulasi data ke Microsoft excel dan data di link kan ke SIMRS. Sedangkan untuk proses pelaporan secara komputerisasi dari cara komputerisasi tadi petugas analising reporting melihat pada SIMRS dan mengisikan data pada Microsoft excel. Setelah semua data sudah diisikan ke Microsoft excel lalu data tersebut disimpan dalam folder tersendiri untuk diimport ke SIRS VI. Proses enrty SIRS VI petugas analising reporting memasukkan data yang sudah disimpan dalam folder ke database melalui SIRS online. Berikut langkah- langkah dalam pelaporan eksternal ke SIRS online.

a. Petugas analising reporting di Rumah Sakit Umum Daerah Pandan Arang Boyolali membuka http://buk.depkes. go.id, kemudian memilih login dan mengisikan username dengan format numerical dan password dengan format alfabetical

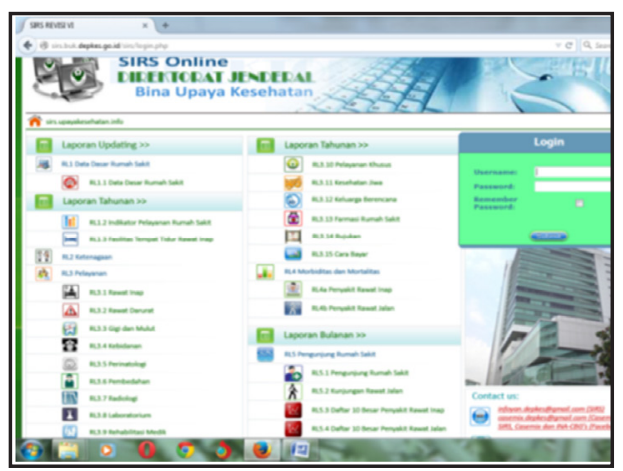

Gambar 4.1 Proses Pengelolaan pelaporan eksternal di Rumah Sakit Umum Daerah Pandan Arang Boyolali 
Pada gambar 4.1 terdapat item login, username, password, laporan updateting yaitu RL1.1 data dasar rumah sakit, laporan tahunan yaitu RL 1.2 indikator pelayanan rumah sakit, RL 1.3 fasilitas tempat tidur rawat inap, RL 2 data ketenagaan, RL 3 data kegiatan pelayanan, RL 3.1 rawat inap, RL 3.2 rawat darurat, RL3.3 gigi dan mulut, RL3.4 kebidanan,RL 3.5 peritanologi, RL 3.6 pembedahan, RL 3.7 radiologi, RL 3.8 laboratorium, RL 3.9 pelayanan rehabilitasi medik, RL 3.10 pelayanan khusus, RL 3.11 kesehatan jiwa, RL 3.12 keluarga berencana, RL 3.13 farmasi rumah sakit, RL 3.14 rujukan, RL 3.15 cara bayar, RL 4 morbiditas dan mortalitas, RL 4.a penyakit rawat inap, RL $4 \mathrm{~b}$ penyakit rawat jalan, laporan bulanan RL 5 pengunjung rumah sakit, RL 5.1 pengunjung rumah sakit, RL 5.2 kunjungan rawat jalan, RL 5.3 daftar 10 penyakit besar rawat inap, RL 5.4 daftar 10 penyakit besar rawat jalan.

b. Import data SIRS VI sesuai dengan data pada RL 1- RL 5, misal jika akan mengimport data kegiatan pelayanan rawat inap maka pilih item RL 3.1

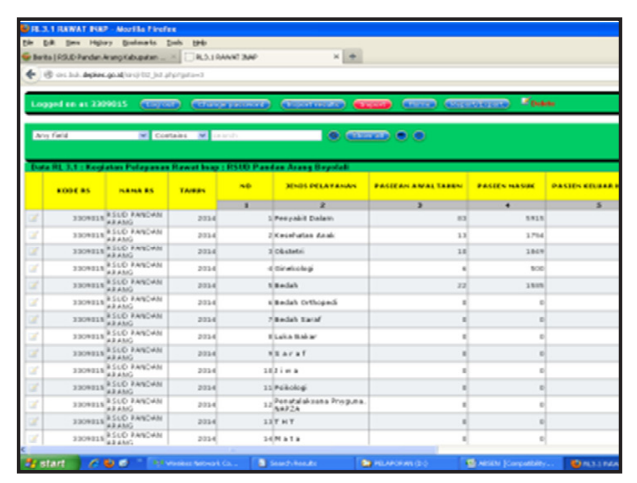

Gambar 4.2 Data Kegiatan Pelayanan Rawat Inap di Rumah Sakit Umum Daerah Pandan Arang Boyolali

Pada gambar 4.2 terdapat item kode rumah sakit, nama rumah sakit, jenis pelayanan, pasien awal masuk, pasien keluar hidup, pasien keluar mati $<48$ jam dan $>48$ jam, jumlah lama dirawat.

c. Klik Browse untuk mencari file yg akan di import misal RL 3.1 data kegiatan pelayanan rawat inap, seperti gambar dibawah ini :

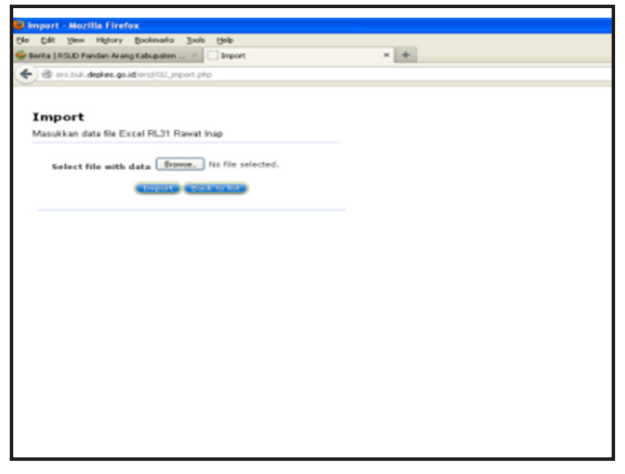

Gambar 4.3 Proses pencarian file excel pelaporan eksternal di Rumah Sakit Umum Daerah Pandan Arang Boyolali

d. Pilih data yang akan di import, misalkan file RL 3.1 data kegiatan pelayanan rawat inap, kemudian klik open untuk membuka file tersebut, seperti gambar dibawah ini :

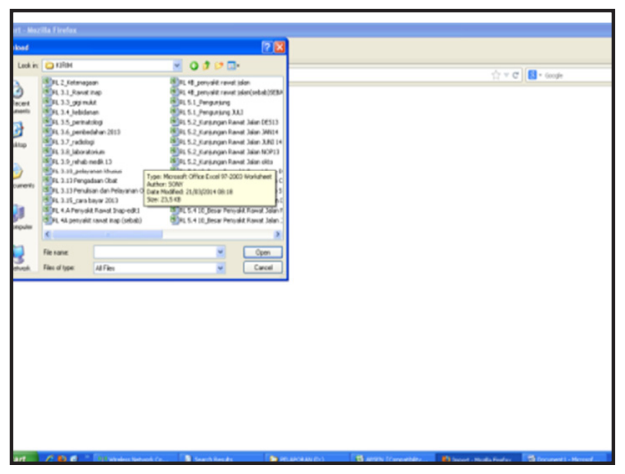

Gambar 4.4 Proses data yang akan diimport di Rumah Sakit Umum Daerah Pandan Arang Boyolali

e. Setelah memilih file RL 3.1 data kegiatan pelayanan rawat inap yang akan di kirim ke SIRS online kemudian klik import, proses pelaporan eksternal selesai dan data sudah masuk ke database SIRS online.

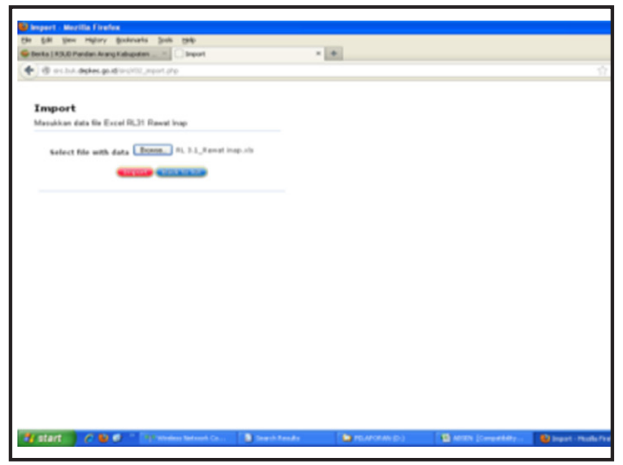

Gambar 4.5 Proses import pelaporan eksternal di Rumah Sakit Umum Daerah Pandan Arang Boyolali 
Proses pelaporan eksternal sebelum dikirim secara online petugas analising reporting melakukan printout dari masing- masing RL 1 yang berisikan data dasar rumah sakit, RL 2 yag berisikan Data Ketenagaan, RL 3 berisikan Data Kegiatan Pelayanan Rumah Sakit, RL 4 berisikan Data Morbiditas atau Mortalitas Pasien, RL 5 Data Bulanan yang berisikan data kunjungan dan data 10 (sepuluh) besar penyakit. Hasil Printout tersebut diserahkan kepada direktur rumah sakit yang berisikan data pelaporan eksternal untuk meminta persetujuan. Setelah meminta persetujuan dari direktur yang berupa acc atau tandatangan dalam bentuk lembaran dengan kertas HVS yang berjumlah satu lembar dan untuk arsip petugas analising reporting. Pada RL 1 - RL 5 tanggal pengirimannya berbeda, untuk RL 1 data dasar rumah sakit yang akan dilaporkan secara update jika sewaktu-waktu ada perubahan data rumah sakit, RL 2- RL 5 data yang dikirim setiap setahun secara periodik sebelum pelaporan eksternal dikirim secara online petugas analising reporting membuat printout yang dilakukan 3 hari sebelum tanggal pengiriman dengan konfirmasi dengan direktur rumah sakit. setelah dimintakan acc atau tandatangan dari direktur petugas melakukan pengecekkan kembali data dari RL 1-5 yang akan dikirim.

\section{PEMBAHASAN}

1. Sumber Data dan Jenis Pelaporan yang digunakan pada pelaporan eksternal di Rumah Sakit Umum Daerah Pandan Arang Boyolali

a. Sumber Data laporan yang digunakan pada pelaporan eksternal di Rumah Sakit Umum Daerah Pandan Arang Boyolali

Sumber data laporan yang digunakan pada pelaporan eksternal di Rumah Sakit Umum Daerah Pandan Arang Boyolali telah sesuai dengan data yang dibutuhkan untuk proses entry pada SIRS VI, yang bersumber dari cara manual dan komputerisasi yang sudah diintegrasi ke Microsoft excel. Sumber data pelaporan eksternal Rumah Sakit Umum Daerah Pandan Arang Boyolali sudah sesuai dengan Sudra (2013) yang menyatakan bahwa sumber data pelaporan eksternal terdiri dari indeks, KIUP, buku register, sensus harian. Akan tetapi sumber data pelaporan eksternal Rumah Sakit Umum Daerah Pandan Arang Boyolali belum diatur dalam Standar Operasional Prosedur rumah sakit, oleh karena itu petugas kebingungan dan tidak dapat menyelesaikan tugasnya dengan baik dalam melaksanakan tugasnya untuk pembuatan pelaporan eksternal.

b. Jenis Pelaporan yang digunakan pada pelaporan eksternal di Rumah Sakit Umum Daerah Pandan Arang Boyolali

Jenis pelaporan yang digunakan pada pelaporan eksternal di Rumah Sakit Umum Daerah Pandan Arang Boyolali sudah sesuai dengan Peraturan Menteri Kesehatan RI Nomor 1171/MENKES/PER/VI/2011 yang menyatakan bahwa RL 1 Data Dasar Rumah Sakit, RL 2 data Ketenagaan, RL 3 data Kegiatan Pelayanan Rumah Sakit, RL 4 Data Keadaan Morbiditas dan Mortalitas, RL 5 Data Bulanan. Untuk jadwal pengiriman RL 1 Data Dasar Rumah Sakit dilaporkan tepat waktu karena data dihasilkan secara update jika sewaktuwaktu ada perubahan data rumah sakit, sedangkan untuk RL 2 Data Ketenagaan, RL 3 Data Kegiatan Pelayanan Rumah Sakit, RL 4 Data Keadaan Morbiditas dan Mortalitas yang dikirim setahun secara periodik setiap tanggal 15 januari tetapi saat melaporkannya tidak tepat waktu melebihi tanggal yang ditentukan, dan RL 5 Data Bulanan yang dilaporkan secara periodik. Hal ini belum sesuai dengan (Rustiyanto, 2014) yang menyatakan bahwa untuk jadwal pengiriman formulir standar yang sudah diisi dari rumah sakit dilakukan paling lambat 15 hari sesudah jangka waktu yang dilaporkan.

2. Proses Pelaporan Eksternal di Rumah Sakit Umum Daerah Pandan Arang Boyolali

Proses Pelaporan Eksternal di Rumah Sakit Umum Daerah Pandan Arang Boyolali dilakukan dengan dua cara yaitu secara manual dan komputerisasi. Proses pelaporan eksternal secara manual telah sesuai dengan data yang dibutuhkan untuk pelaporan eksternal SIRS 
VI untuk pembuatan RL 2 data ketenagaan, RL 3.1 pelyanan rawat inap, RL 3.3 gigi dan mulut, RL 3.6 pembedahan, RL 3.7 radiologi, RL 3.8 laboratorium, RL 3.9 rehabilitasi medik, RL 3.11 kesehatan jiwa, RL 3.14 kegiatan rujukan. Dari cara manual tadi petugas analising reporting mengumpulkan data dengan datang ke setiap unit dan dilakukan sebulan sekali. Setelah data terkumpul petugas merekapitulasi data ke Microsoft excel dan data di link kan ke SIMRS, hal ini mengakibatkan petugas harus bekerja dua kali. Sedangkan untuk proses pelaporan eksternal secara komputerisasi juga sudah sesuai dengan data yang dibutuhkan untuk pelaporan ekstenal SIRS VI untuk RL 1.1 data dasar rumah sakit, RL 1.2 indikator pelayanan rumah sakit, RL 1.3 fasilitas tempat tidur rawat inap, RL 3.2 rawat darurat, RL 3.4 kebidanan, RL 3.5 perinatologi, RL 3.10 pelayanan khusus, RL 3.12 keluarga berencana, RL 3.13 apotik, RL 3.15 cara bayar, RL 4 morbiditas dan mortalitas, RL 5 data bulanan. Petugas analising reporting hanya melihat pada SIMRS jadi tidak membutuhkan waktu lama untuk membuat pelaporan eksternal. Proses entri pelaporan eksernal sudah sesuai dengan data yang dibutuhkan untuk pelaporan eksternal yang berpedoman pada KepMenKes RI Nomor 1171/MENKES/PER/VI/2011. Akan tetapi dalam hal proses pengelolaan pelaporan eksternal ini Rumah Sakit Umum Daerah Pandan Arang Boyolali belum melakukan Standar Operasional Prosedur yang mengatur tentang pembuatan pelaporan rumah sakit berdasarkan SIRS VI tahun 2011. Namun dalam pembuatan, pelaporan rumah sakit tidak sesuai dengan Standar Operasional Prosedur yang berlaku saat ini. Pembuatan pelaporan sudah sesuai dengan JUKNIS 2011 SIRS VI. Sebelum proses pengiriman petugas analising reporting membuat printout untuk dimintakan acc atau tandatangan kepada direktur. Printout tersebut dibuat 3 hari sebelum tanggal pengiriman dengan konfirmasi dengan direktur rumah sakit. Tetapi petugas analising reporting dalam waktu 3 hari sulit untuk menemui direktur rumah sakit sehingga petugas analising reporting harus menunggu dan pengiriman pelaporan jadi terlambat.

\section{SIMPULAN}

1. Sumber data pelaporan sudah sesuai dengan data yang dibutuhkan untuk proses entri pelaporan eksternal pada SIRS VI akan tetapi belum ada SOP yang memuat tentang sumber data pelaporan. Jenis data pelaporan eksternal sudah sesuai dengan PerMenKes RI Nomor 1171/ MENKES/PER/VI/2011.

2. Proses Pelaporan Eksternal dilakukan dengan cara manual dan komputerisasi telah sesuai dengan pembuatan pelaporan yang dilakukan oleh petugas analising reporting di Rumah Sakit Umum Daerah Pandan Arang Boyolali. Untuk proses pelaporan sudah memberlakukan SOP rumah sakit. Akan tetapi pada proses pelaporan eksternal Rumah sakit Umum Daerah Pandan Arang Boyolali belum sesuai dengan SOP yang berlaku saat ini. Untuk proses pengiriman telah dilakukan dengan melakukan pengesahan kepada direktur dengan konfirmasi dalam waktu 3 hari, akan tetapi petugas sulit untuk menemukan direkturdalam waktu 3 hari.

\section{DAFTAR PUSTAKA}

Bustami, MS, MQIH. 2011. Penjaminan Mutu Pelayanan Kesehatan dan Akseptabilitasnya. Jakarta : Erlangga.

Departemen Kesehatan RI. 2006. Pedoman Penyelenggaraan dan Prosedur Rekam Medis Rumah Sakit di Indonesia. Revisi II. Jakarta:Direktorat Jenderal Bina Pelayanan Medik.

Djarwanto Ps, Se. 2001. Mengenal Beberapa Uji Statistik dalam Penelitian. Yogyakarta : Liberty Yogyakarta.

KepMenKes RI. 2011. Juknis SIRS 2011 (Sistem Informasi Rumah Sakit). Jakarta : KepMenKes RI.

Notoatmodjo, S. 2010. Metodelogi Penelitian Kesehatan. Edisi Revisi. Jakarta. PT Rineka Cipta.

PerMenKes RI No. 1171/MENKES/PER/VI/2011. Sistem Informasi Rumah Sakit. Jakarta.

Rustiyanto, E. 2014. Sistem Informasi Manajemen Rumah Sakit. Yogyakarta :Politeknik Kesehatan Pertama Indonesia.

Sudra RI. 2013. Rekam Medis. Tangerang Selatan: Universitas Terbuka.

Sugiyono. 2010 . Metodelogi Penelitian (Pendekatan Kuantitatif, Kualitatif, dan R\&D). Bandung. Alfabeta. 